\title{
Norwegian-Polish Bilateral Trade Developments since 1990
}

\author{
Gorm Jacobsen \\ University of Agder \\ Norway \\ gorm.jacobsen@uia.no
}

\begin{abstract}
Since 1990 there has been a significant growth in Norwegian-Polish bilateral trade. Of key interest to this work is to identify the main industries driving bilateral trade and to what extent this trade is in similar or different goods, suggesting either industrial convergence or specialization, respectively. When measured in nominal terms, up until 2014, Norway's exports to Poland have increased by a factor of 16 , while Norway's imports from Poland have increased by a factor of 32 during the same period. Over the period 2005-2014 Norwegian imports and exports have both increased by an approximate $200 \%$.This can be strongly attributed to Poland's membership in the European Union since 2004 and the fact that Norway has a free trade agreement with the EU. Therefore, taking into account not only the significant expansion in bilateral trade between these two countries but also the differences in their respective structures of industry, this work seeks to analyse the main factors behind the development of this trade.
\end{abstract}

Keywords: Bilateral Trade, Norway, Poland

JEL classification: F10, F12, F15

\section{INTRODUCTION}

From a theoretical point of view international trade and industrial comparative advantage can be explained by the Hecksher-Ohlin model, which discusses trade in different goods. This is also referred to as inter-industry trade. However a substantial part of international trade conducted in the world today is in similar goods and known as intra-industry trade. This cannot be explained by the above mention model, but by product differentiation, economics of scale and imperfect competition. This type of trade can be measured using the Grubel-Lloyd index. It is this latter model that can reveal that proportion of a country's trade conducted in similar goods (intra-industry) reflecting industrial convergence and that the share of trade which is in different goods (inter-industry). In terms of the former, Poland, whose main trading partner is Germany, has been integrated into the EU supply and production networks since the early 1990's and its bilateral trade is dominantly made up of goods supplied by similar industries. Norway on the other hand is resource rich and trades in different goods. For this reason the theoretical application of the Grubel-Lloyd 
index, followed by an empirical analysis of the results generated by the model is intended to reveal the direction, structure and types of goods traded between both countries.

The research follows the United Nations (UN), Standard International Trade Classification (SITC) structure in which goods traded are categorized according to ten main industrial categorizations. Each of these is disaggregated into digits ranging from one onwards, where one represents the UN commodity groups, two represents the broad industrial sector, three represents the industry and four represents those parts, materials and accessories that are used in the production and/or assembly of a given product. This system of disaggregation extends well beyond the four-digit group, expanding the numbers of items used in the production of a given good into the thousands. This work analyses Norwegian-Polish bilateral trade using the two-digit level of disaggregation and the Norwegian Kroner (NOK) as the main currency. The data used in this research was obtained from the Central Bureau of Statistics in Norway. Of recent works in this topic is Clowes \& Choros-Mrozowska (2013) studying Chinese-EU bilateral trade in the selected sub-sectors of SITC 7. The results show that products with low and low-to-medium levels of technology are more integrated (SITC 74-Industrial machinery and SITC 77-Electrical machinery) than SITC 75 (Office machines) and SITC 76 (Telecommunications equipment) that are more sophisticated technology and requires more skilled workforce.

From the list below, which shows UN commodity groups at the single-digit level this work will focus on the four most important sectors of trade between the two countries; i.e. SITC 0, SITC 6, SITC 7 and SITC 8 for the years 2005 and 2014. The application of the Grubel Lloyd index will enable us to determine whether the exchange of trade across these four categories is of inter-industry or intra-industry character. The main results of this study is that most of the trade between Norway and Poland both in 2005 and 2014 are in different goods (inter-industry character). The main reason for that is probably that Norway is a small resource rich country.
United Nations Commodity Groups (single digit)): ${ }^{1}$
SITC 0 - Food and live animals
SITC 1 - Beverages and tobacco
SITC 2 - Crude materials, inedible, except fuels
SITC 3 - Mineral fuels, lubricants and related materials
SITC 4 - Animals and vegetable oils, fats and waxes
SITC 5 - Chemicals and related products
SITC 6 - Manufactured goods classified chiefly by material
SITC 7 - Machinery and transport equipment
SITC 8 - Miscellaneous manufactured articles
SITC 9 - Commodities and transactions not classified in the listed SITC

Part one of this research presents data regarding the development of bilateral trade between these two countries. The main finding is that Norway's exports to Poland have increased by a factor of 16 while Norway's imports from Poland have increased by a factor of 32 since the introduction of market economy in Poland in 1990. Part two presents the Grubel-Lloyd index which is applied to study if this trade is of intra-industry character, i.e. trade in same goods or in different goods suggesting trade based on compara-

For orientational purposes the system of disaggregation can be explained using the above list of UN commodity groups as follows: SITC 6: Manufactured goods classified chiefly by material;

SITC 66: Non-metallic mineral manufactures, n.e.s.;

SITC 666: Pottery 
tive advantages. Then follows an empirical part discussing the developments of the Grubel-Lloyd index in SITC 0, SITC 6, SITC 7 and SITC 8. These sectors are chosen since they are most important measured in Norwegian Kroner when it comes to trade between these two countries.

\section{EMPIRICAL BACKGROUND}

The following graph depicts Norway's trade with Poland for the years 2005 and 2014. The first observation concerns not only the scale of change over time, but the actual growth rates in Norway's bilateral trade with Poland. For example, over the period 2005 to 2014 the average rate of Norwegian export growth was 12.9 percent, while its imports grew by an average of 12.7 percent. The volume of trade was almost similar (appendix one) leaving a small Norwegian trade deficit. The second observation concerns the actual balance of trade over time. From 1990 to 1999 Norway recorded positive trade surpluses throughout the whole period. This can be attributed to the fact that the Polish economy was implementing economic reforms during those earlier years and was privatizing, restructuring and modernizing its industrial structure. Thus, the types of goods that Poland could export were largely in low demand in Norway. In respect of Norwegian exports to Poland during this period the volume when measured in millions of NOK was gradual increasing from 977 million NOK in 1990 to 3.0 billion NOK in 1999 (see appendix one). Observation of appendix one further reveals that there were significant parallel increases in trade, especially from 2004 onwards, which was when Poland together with a further nine countries became members of the European Union (EU). During the $21^{\text {st }}$ century, with the exception of 2001, 2008, 2010 and 2011, Norway was running a trade deficit with Poland reaching its deepest point at 3.1 billion NOK in 2009. However, the very fact that Norway has a positive surplus in its total trade internationally, due to its vast natural energy resources, suggests that its deficit with Poland is insignificant at a macro level. This work will therefore now turn to the theoretical modeling technique that will be applied in this work.

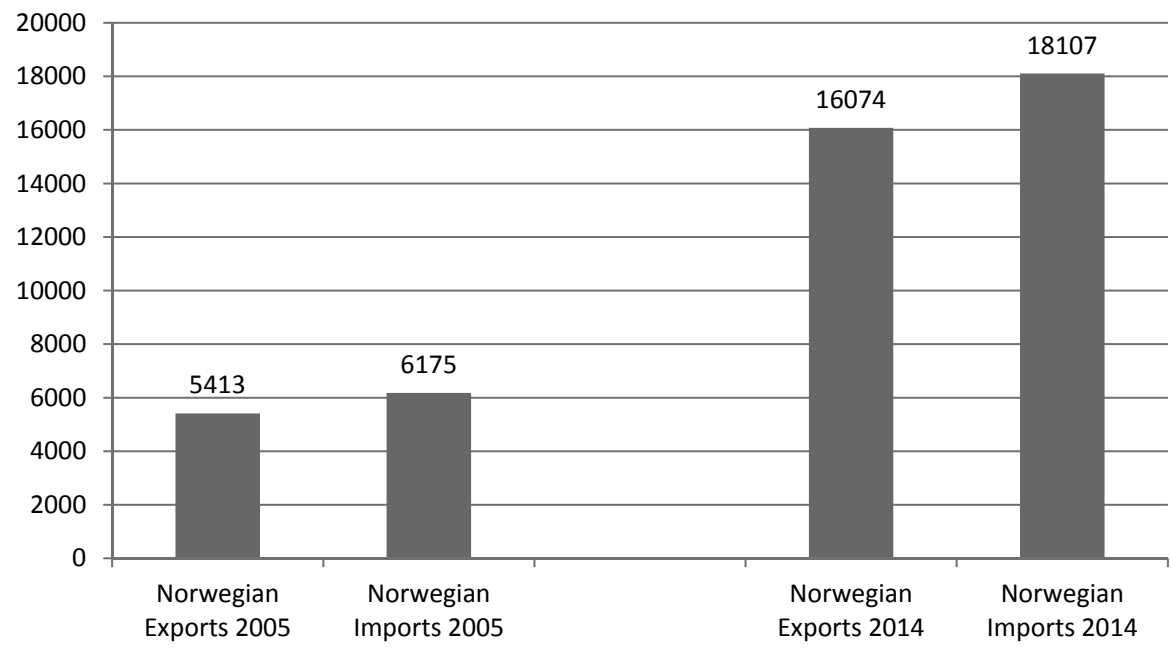

Figure 1. Norwegian-Polish Bilateral Trade in 2005 \& 2014 (millions NOK)

Source: www.ssb.no. 


\section{THEORETICAL FRAMEWORK}

The modeling technique that will be applied in this work is known as the Grubel-Lloyd index (Grubel $\&$ Lloyd, 1975). The model generates an index out of one hundred and reveals to what extent a country's trade is more intra-industry driven, suggesting industrial convergence and what proportion of that trade is due to the exchange of different goods. In terms of the latter, this may indicate industrial specialization and possibly comparative advantage. The Grubel-Lloyd index calculates intra-industry trade using the following index and is written as:

$$
I I T=\left[\frac{\Sigma\left(x_{i}+m_{i}\right)-\Sigma\left(\left|x_{i}-m_{i}\right|\right)}{\Sigma\left(x_{i}+m_{i}\right)}\right] * 100
$$

where $\mathrm{x}_{\mathrm{i}}$ represents exports from industry $i$ and $\mathrm{m}_{\mathrm{i}}$ represents imports from industry $i$.

IIT is the level of intra-industry trade and is measured out of one hundred. Observation of the given model reveals that the value for IIT can be calculated by subtracting the balance of trade for a given industry from the sum of total trade. The obtained value is then divided by the sum of total trade. The end value is multiplied by one hundred to provide an index.

In terms of analysis, a value closer to one hundred $(>50)$ suggests industrial convergence in bilateral trade. This could be in, for example, trade in manufactured goods, machinery etc. The value of trade in monetary terms may vary depending on a country's industrial capacity and scale of technology. Oppositely, a value closer to zero $(<50)$ suggests that the degree of industrial convergence is lower and is referred to as inter-industry trade. In such lower convergence coupled with higher export volumes in monetary terms could imply industrial specialization and possibly comparative advantage.

\section{ANALYSIS OF RESULTS}

\section{SITC 0 - Food and live animals.}

Tables one and two provide the results calculated for Norwegian-Polish bilateral trade for SITC 0. A closer look at the figures shows that by the far most important sector when it comes to exports to Poland is the Norwegian fishing industry (SITC 0), which accounted for almost 40 percent of Norway's exports to Poland in 2014 compared to around 27 percent in 2005; see appendix two. Almost all exports from this category come from SITC 03, and are made up of sea food. During this period exports from this sector increased by 338 per cent, while Norwegian total exports to Poland increased by 197 percent. This is a result of the strong economic growth and therefore also strong growth in private consumption in Poland over the years. Furthermore, fish imported into Poland is also for processing purposes prior to exporting into the European Union. 
Norway's trade with Poland (1000 NOK) \& Intra-industry trade (2005)

\begin{tabular}{|c|c|c|c|c|c|c|}
\hline Industry & $\mathrm{m}_{\mathrm{i}}$ & $\%$ & $\mathrm{x}_{\mathrm{i}}$ & $\%$ & $\mathrm{x}_{\mathrm{i}}-\mathrm{m}_{\mathrm{i}}$ & IIT $_{\mathrm{i}}$ \\
\hline SITC 00 & 229 & 0.1 & 17 & - & -212 & 13.8 \\
\hline SITC 01 & 19993 & 7.9 & 0 & 0.0 & -19993 & 0.0 \\
\hline SITC 02 & 0 & 0.0 & 2 & - & 2 & 0.0 \\
\hline SITC 03 & 16702 & 6.6 & 1454312 & 98.9 & 1437610 & 2.3 \\
\hline SITC 04 & 12748 & 5.0 & 411 & 0.03 & -12337 & 6.2 \\
\hline SITC 05 & 114300 & 45.0 & 967 & 0.07 & -113333 & 1.7 \\
\hline SITC 06 & 3166 & 1.2 & 124 & 0.01 & -3042 & 7.5 \\
\hline SITC 07 & 12375 & 4.9 & 486 & 0.03 & -11889 & 7.6 \\
\hline SITC 08 & 20518 & 8.1 & 13132 & 0.9 & -7386 & 78.1 \\
\hline SITC 09 & 54061 & 21.3 & 584 & 0.04 & -53477 & 2.1 \\
\hline Total & 254093 & 100 & 1470035 & 100 & 1215942 & \\
\hline
\end{tabular}

Source: www.ssb.no.

It is clear that this trade has to do with Norway's comparative advantage in this industry. Tables one and two confirm this finding via the low value for the ITT.

Table 2

Norway's trade with Poland (1000 NOK) \& Intra-industry trade (2014)

\begin{tabular}{|c|c|c|c|c|c|c|}
\hline Industry & $\mathrm{m}_{\mathrm{i}}$ & $\%$ & $\mathrm{x}_{\mathrm{i}}$ & $\%$ & $\mathrm{x}_{\mathrm{i}}-\mathrm{m}_{\mathrm{i}}$ & IIT $_{\mathrm{i}}$ \\
\hline SITC 00 & 563 & 0.07 & 0 & 0.0 & -563 & 0.0 \\
\hline SITC 01 & 2137 & 0.3 & 843 & 0.01 & -1294 & 56.6 \\
\hline SITC 02 & 16201 & 1.9 & 0 & 0.0 & -16201 & 0.0 \\
\hline SITC 03 & 79859 & 9.4 & 6375051 & 99.4 & 6295192 & 2.5 \\
\hline SITC 04 & 86034 & 10.1 & 93 & - & -85941 & 0.2 \\
\hline SITC 05 & 344122 & 40.5 & 679 & 0.01 & -343443 & 0.4 \\
\hline SITC 06 & 18549 & 2.2 & 0 & 0.0 & -18549 & 0.0 \\
\hline SITC 07 & 100371 & 11.8 & 8087 & 0.1 & -92284 & 14.9 \\
\hline SITC 08 & 83288 & 9.8 & 452 & 0.01 & -82836 & 1.1 \\
\hline SITC 09 & 118281 & 13.9 & 28848 & 0.4 & -89433 & 39.2 \\
\hline Total & 849405 & 100 & 6414052 & 100 & 5564647 & \\
\hline
\end{tabular}

Source: www.ssb.no. 
List of SITC 0 products

0 - Food and live animals

00 - Live animals other than animals of division 03

01 - Meat and meat preparations

02 - Dairy products and birds' eggs

03 - Fish (not marine mammals), crustaceans, molluscs and aquatic invertebrates, and preparations thereof

04 - Cereals and cereal preparations

05 - Vegetables and fruit

06 - Sugars, sugar preparations and honey

07 - Coffee, tea, cocoa, spices, and manufactures thereof

08 - Feeding stuff for animals (not including unmilled cereals)

09 - Miscellaneous edible products and preparations

\section{SITC 6 - Manufactured goods classified chiefly by material.}

Like Norwegian exports of goods from SITC 0 the dominant exports of goods from SITC 6 can be explained by the Hecksher-Ohlin theory of international trade. From this category "Non-ferrous metals" (SITC 68) accounted for one third of the exports in 2005. Almost a decade later these exports accounted for half of the sector (see tables three and four). Norway's comparative advantages in the production and supply of non-ferrous metals, is due to the availability of electricity supplied at low costs. Producers in this sector benefit from electricity prices below the market average level.

Table 3

Norway's trade with Poland (1000 NOK) \& Intra-industry trade (2005)

\begin{tabular}{|c|c|c|c|c|c|c|}
\hline Industry & $\mathrm{m}_{\mathrm{i}}$ & $\%$ & $\mathrm{x}_{\mathrm{i}}$ & $\%$ & $\mathrm{x}_{\mathrm{i}}-\mathrm{m}_{\mathrm{i}}$ & IIT $_{\mathrm{i}}$ \\
\hline SITC 60 & & & & & & \\
\hline SITC 61 & 2647 & 0.2 & 418 & 0.03 & -2229 & 27.3 \\
\hline SITC 62 & 17448 & 1.1 & 2610 & 0.2 & -14838 & 26.0 \\
\hline SITC 63 & 266053 & 16.5 & 6454 & 0.5 & -259599 & 4.7 \\
\hline SITC 64 & 68170 & 4.2 & 70039 & 5.4 & 1869 & 98.6 \\
\hline SITC 65 & 64265 & 4.0 & 125608 & 9.7 & 61343 & 67.7 \\
\hline SITC 66 & 174051 & 10.8 & 9084 & 0.7 & -164967 & 9.9 \\
\hline SITC 67 & 290651 & 18.0 & 479691 & 37.1 & 189040 & 75.5 \\
\hline SITC 68 & 14875 & 0.9 & 441362 & 34.2 & 426487 & 6.5 \\
\hline SITC 69 & 718628 & 44.4 & 156962 & 12.1 & -561666 & 35.9 \\
\hline Total & 1616786 & 100 & 1292227 & 100 & -324559 & \\
\hline
\end{tabular}

Source: www.ssb.no.

The export of iron and steel to Poland (SITC 67) accounted for 37.1 percent in 2005, but its share had fallen to 25.8 percent in 2014. Bilateral trade in this sector reflects a high degree of convergence (see tables three and four). Norway has been a traditional producer of iron and steel and this is due to its vast resources of medium grade iron ores (IBRD 1948). 
Norway's trade with Poland (1000 NOK) \& Intra-industry trade (2014)

\begin{tabular}{|c|c|c|c|c|c|c|}
\hline Industry & $\mathrm{m}_{\mathrm{i}}$ & $\%$ & $\mathrm{x}_{\mathrm{i}}$ & $\%$ & $\mathrm{x}_{\mathrm{i}}-\mathrm{m}_{\mathrm{i}}$ & IIT $_{\mathrm{i}}$ \\
\hline SITC 60 & & & & & & \\
\hline SITC 61 & 11517 & 0.2 & 308 & 0.01 & -11209 & 5.2 \\
\hline SITC 62 & 98959 & 2.1 & 35507 & 1.1 & -63452 & 52.8 \\
\hline SITC 63 & 727769 & 15.1 & 8787 & 0.3 & -718982 & 2.4 \\
\hline SITC 64 & 249054 & 5.2 & 302406 & 9.4 & 53552 & 90.3 \\
\hline SITC 65 & 124735 & 2.6 & 21740 & 0.7 & -102995 & 29.7 \\
\hline SITC 66 & 686685 & 14.3 & 7033 & 0.2 & -679652 & 2.0 \\
\hline SITC 67 & 479496 & 10.0 & 829725 & 25.8 & 350229 & 73.2 \\
\hline SITC 68 & 85710 & 1.8 & 1696278 & 52.7 & 1610568 & 9.6 \\
\hline SITC 69 & 2351201 & 48.8 & 314078 & 9.8 & -2037123 & 23.6 \\
\hline Total & 4815126 & 100 & 3215862 & 100 & -1599264 & \\
\hline
\end{tabular}

Source: www.ssb.no.

Manufactured metal products (SITC 69) are Norway's single largest import from Poland. Between 2005 and 2014 Polish exports of these products increased by 227 percent, from more than 718 million to 2.3 billion NOK. This represents an average yearly increase of 9.5 percent.

\section{List of SITC 6 products}

6 - Manufactured goods classified chiefly by material 61 - Leather, leather manufactures n.e.s., and dressed furskins 62 - Rubber manufactures, n.e.s. 63 - Cork and wood manufactures (excluding furniture) 64 - Paper, paperboard and articles of paper pulp, of paper or of paperboard 65 - Textile yarn, fabrics, madeup articles, n.e.s., and related products 66 - Non-metallic mineral manufactures, n.e.s. 67 - Iron and steel 68 - Non-ferrous metals 69 - Manufactures of metals, n.e.s.

\section{SITC 7 - Machinery and transport equipment.}

Tables five and six provide the results calculated for Norwegian-Polish bilateral trade in the exchange of machinery and transport equipment for 2005 and 2014. Like the other sectors, sector 7 can be sub-divided into ten core industrial trade sectors at a two digit level.

Table 5

Norway's trade with Poland (1000 NOK) \& Intra-industry trade (2005)

\begin{tabular}{|c|c|c|c|c|c|c|}
\hline Industry & $\mathrm{m}_{\mathrm{i}}$ & $\%$ & $\mathrm{x}_{\mathrm{i}}$ & $\%$ & $\mathrm{x}_{\mathrm{i}}-\mathrm{m}_{\mathrm{i}}$ & IIT $_{\mathrm{i}}$ \\
\hline 1 & 2 & 3 & 4 & 5 & 6 & 7 \\
\hline SITC 70 & & & & & & \\
\hline SITC 71 & 44651 & 2.3 & 67315 & 9.6 & 22664 & 79.8 \\
\hline SITC 72 & 86756 & 4.5 & 162463 & 23.2 & 75707 & 69.6 \\
\hline SITC 73 & 11230 & 0.6 & 3824 & 0.5 & -7414 & 50.8 \\
\hline
\end{tabular}




\begin{tabular}{|c|c|c|c|c|c|c|}
\hline 1 & 2 & 3 & 4 & 5 & 6 & 7 \\
\hline SITC 74 & 144128 & 7.5 & 214214 & 30.6 & 70086 & 80.4 \\
\hline SITC 75 & 3081 & 0.2 & 7473 & 1.1 & 4392 & 58.4 \\
\hline SITC 76 & 204657 & 10.7 & 40012 & 5.7 & -164645 & 32.7 \\
\hline SITC 77 & 385044 & 20.2 & 170043 & 24.3 & -215001 & 61.3 \\
\hline SITC 78 & 370489 & 19.4 & 29617 & 4.2 & -340872 & 14.8 \\
\hline SITC 79 & 659964 & 34.6 & 5245 & 0.7 & -654719 & 1.6 \\
\hline Total & 1910001 & 100 & 699664 & 100 & -1210337 & \\
\hline
\end{tabular}

Source: www.ssb.no.

The most important sub-sector when it comes to Norwegian exports is SITC 74 (General industrial machinery and equipment). The level of intra-industry trade fell by more than seven index points over the entire period, though industrial exchange and convergence is high. However as seen from tables five and six the Grubel-Lloyd index is well below 50 in 6 out of 9 sectors in 2014 (see far-right column), while the same number was only 3 nine years earlier. This indicates significant differences in industrial production and is primary due to Norwegian outsourcing of production to Poland and abroad. This explains Norway's trade deficit across these industries and rising inter-industry trade (Evensen, 2015).

Table 6

Norway's trade with Poland (1000 NOK) \& Intra-industry trade (2014)

\begin{tabular}{|c|c|c|c|c|c|c|}
\hline Industry & $\mathrm{m}_{\mathrm{i}}$ & $\%$ & $\mathrm{x}_{\mathrm{i}}$ & $\%$ & $\mathrm{x}_{\mathrm{i}}-\mathrm{m}_{\mathrm{i}}$ & IIT $_{i}$ \\
\hline SITC 70 & & & & & & \\
\hline SITC 71 & 50651 & 0.7 & 424823 & 19.6 & 374172 & 21.3 \\
\hline SITC 72 & 473318 & 6.4 & 475525 & 22.0 & 2207 & 99.8 \\
\hline SITC 73 & 50355 & 0.7 & 4646 & 0.2 & -45709 & 17.3 \\
\hline SITC 74 & 1227756 & 16.6 & 705255 & 32.6 & -522501 & 73.0 \\
\hline SITC 75 & 455894 & 6.2 & 22356 & 1.0 & -433538 & 9.4 \\
\hline SITC 76 & 551960 & 7.5 & 50311 & 2.3 & -501649 & 66.7 \\
\hline SITC 77 & 1330533 & 18.0 & 286345 & 13.2 & -1044188 & 35.4 \\
\hline SITC 78 & 1746084 & 23.6 & 165653 & 7.6 & -1580431 & 17.3 \\
\hline SITC 79 & 1502518 & 20.3 & 31310 & 1.4 & -1471208 & 4.1 \\
\hline Total & 7389068 & 100 & 2166223 & 100 & -5222845 & \\
\hline
\end{tabular}

Source: www.ssb.no.

\section{List of SITC 7 products}

7 - Machinery and transport equipment 71 - Power-generating machinery and equipment 72 Machinery specialized for particular industries 73- Metalworking machinery 74 - General industrial machinery and equipment, n.e.s., and machine parts, n.e.s. 75 - Office machines and automatic data-processing machines 76 - Telecommunications and sound-recording and reproducing apparatus and equipment 77 - Electrical machinery, apparatus and appliances, n.e.s., and electrical parts thereof (including non-electrical counterparts, n.e.s., of electrical household-type equipment) 78 - Road vehicles (including air-cushion vehicles) 79 - Other transport equipment 


\section{SITC 8 - Miscellaneous articles.}

The figures for the last sector in these analyses; i.e. SITC 8 are presented in the next two tables.

Table 7

Norway's trade with Poland (1000 NOK) \& Intra-industry trade (2005)

\begin{tabular}{|c|c|c|c|c|c|c|}
\hline Industry & $\mathrm{m}_{\mathrm{i}}$ & $\%$ & $\mathrm{x}_{\mathrm{i}}$ & $\%$ & $\mathrm{x}_{\mathrm{i}}-\mathrm{m}_{\mathrm{i}}$ & IIT $_{i}$ \\
\hline SITC 80 & & & & & & \\
\hline SITC 81 & 62564 & 4.5 & 9779 & 5.9 & -52785 & 27.0 \\
\hline SITC 82 & 594394 & 42.8 & 16661 & 10.0 & -577733 & 5.5 \\
\hline SITC 83 & 896 & 0.1 & 36 & 0.02 & -860 & 7.7 \\
\hline SITC 84 & 423588 & 30.5 & 8133 & 4.9 & -415455 & 3.8 \\
\hline SITC 85 & 13971 & 1.0 & 70 & 0.04 & -13901 & 1.0 \\
\hline SITC 86 & - & - & - & - & - & - \\
\hline SITC 87 & 16657 & 1.2 & 62320 & 37.3 & 45663 & 42.2 \\
\hline SITC 88 & 6695 & 0.5 & 1111 & 0.7 & -5584 & 28.5 \\
\hline SITC 89 & 271385 & 19.5 & 68899 & 41.3 & -202486 & 40.5 \\
\hline Total & 1390150 & 100 & 167010 & 100 & -1223140 & \\
\hline
\end{tabular}

Source: www.ssb.no.

Table 8

Norway's trade with Poland (1000 NOK) \& Intra-industry trade (2014)

\begin{tabular}{|c|c|c|c|c|c|c|}
\hline Industry & $\mathrm{m}_{\mathrm{i}}$ & $\%$ & $\mathrm{x}_{\mathrm{i}}$ & $\%$ & $\mathrm{x}_{\mathrm{i}}-\mathrm{m}_{\mathrm{i}}$ & IIT $_{\mathrm{i}}$ \\
\hline SITC 80 & & & & & & \\
\hline SITC 81 & 351944 & 10.6 & 27486 & 4.9 & -324458 & 14.5 \\
\hline SITC 82 & 1500661 & 45.0 & 23466 & 4.2 & -1477195 & 3.1 \\
\hline SITC 83 & 8683 & 0.3 & 602 & 0.1 & -8081 & 13.0 \\
\hline SITC 84 & 286928 & 8.6 & 7703 & 1.4 & -279225 & 5.2 \\
\hline SITC 85 & 14722 & 0.4 & 858 & 0.2 & -13864 & 11.0 \\
\hline SITC 86 & - & - & - & - & - & - \\
\hline SITC 87 & 194288 & 5.8 & 161829 & 28.9 & -32459 & 90.9 \\
\hline SITC 88 & 25309 & 0.8 & 1329 & 0.2 & -23980 & 10.0 \\
\hline SITC 89 & 949595 & 28.5 & 336061 & 60.1 & -613534 & 52.3 \\
\hline Total & 3332130 & 100 & 559334 & 100 & -2772796 & \\
\hline
\end{tabular}

Source: www.ssb.no.

\section{List of SITC 8 products}

8 - Miscellaneous manufactured articles 81 - Prefabricated buildings; sanitary, plumbing, heating and lighting fixtures and fittings, n.e.s. 82 - Furniture and parts thereof; bedding, mattresses, mattress support, cushions and similar stuffed furnishings 83 - Travel goods, handbags and similar containers 84 - Articles of apparel and clothing accessories 85 - Footwear 87 - Professional, scientific and controlling instruments and apparatus, n.e.s. 88 - Photographic apparatus, equipment and supplies and optical goods, n.e.s.; watches and clocks 89 - Miscellaneous manufactured articles, n.e.s. 
From the Grubel-Lloyd index we see that most trade in 2005 was in different goods, since all indexes were below 50. The situation was almost the same one decade later except products classified as SITC 87 and SITC 89. In terms of the former these products are used in veterinary, dental and medical practices. The Norwegian deficit in trade in this sector suggests that Poland has benefited from foreign direct investment and developed products embodied with higher levels of technological sophistication.

\section{CONCLUSION}

Since the implementation of market reforms in Poland twenty-five years ago the country has been integrated into European Union supply and production networks. On the basis of this one may expect that bilateral trade between Norway and Poland would be to a great extent of an intra-industry character. This belief is strengthened by the fact that Poland has been one of the countries with the highest level of foreign direct investment in Europe since 1995. However the fact that Norway is a small resource rich country ultimately gives rise to trade in different goods which is revealed in this research to be of an inter-industry character. The exchange of goods between these two countries will therefore be driven by industries with strong comparative advantages in production for the years to come. This is due to the fact that predominantly Norwegian exports of seafood - especially salmon - have increased by 338 percent over a period of nine years, representing a yearly increase of 14.5 percent. In contrast the Polish exports of iron and steel to Norway has increased by 227 percent over the time period measured, equating to an average 9.5 percent per year. This is consistent with increased investment into building and construction in Norway in recent years.

When Norway becomes less dependent of natural resources like oil and gas due to lower oil price and the development of a greener economy, it could be subject for research how it will affect Norwegian future trade in general and trade with Poland special.

Already in 1975 did research by Grubel \& Lloyd show that more than half of world trade were in similar goods. The results from this research, which shows that the main part of trade between Norway and Poland are based on comparative advantages and not are of intra-industry character, are therefore not in line with the typical development of international trade pattern.

\section{BIBLIOGRAPHY}

Balassa, B., (1986), Intra-Industry Trade Among Exporters of Manufactured Goods, [in:] Imperfect Competition and International Trade, Ed. Greenaway, D., Tharakan, P., pages 108-112.

Brenton, P., Di Mauro, F., (1998), Trade between the CEECs and the EU, The World Economy, Vol. 21, Blackwell Publishers; Oxford.

Clowes D., Choroś-Mrozowska, D., (2013), Chinese-EU Bilateral Trade (2007-2011), Journal of International Studies, Vol. 6, No2.

Dunning, J., (1993), Multinational Enterprises and the Global Economy, Addison-Wesley, Wokingham.

Grubel, H., Lloyd, P., (1975), Intra-Industry Trade, The Theory of Measurement of International Trade in Differentiated Products, Macmillan Press; London.

Huang, Andrew C., (1948): The Iron and Steel Industry of Norway, International Bank for Reconstruction and Development.

Jacobsen, G., (2010), Poland - Twenty Years With Market Economy, International Business and Economics Research Journal, Vol. 9, No 11. 
Jacobsen, G., (2011), Turning Poland Around - The Polish Economy 1990 - 2009, Journal of Business Case Studies, Vol.7, No 5 .

Mikić, M., (1998), International Trade, St. Martin’s Press Inc.

Norman, V.D., Orvedal L., (2010) En Liten Åpen Økonomi, Gyldendal Akademisk.

Nygård Evensen, Tonje., (2015), Goods Sent Abroad For Processing and Merchandising in the Norwegian National Accounts, Central Bureau of Statistics, Norway.

Appendix 1

Trade in goods between Norway and Poland in million NOK.

\begin{tabular}{|c|c|c|c|}
\hline Year & Export million NOK & Import million NOK & Trade balance million NOK \\
\hline 1990 & 977 & 558 & 419 \\
\hline 1991 & 1812 & 605 & 1206 \\
\hline 1992 & 1950 & 731 & 1219 \\
\hline 1993 & 2249 & 804 & 1445 \\
\hline 1994 & 2343 & 948 & 1395 \\
\hline 1995 & 2285 & 1095 & 1191 \\
\hline 1996 & 2212 & 1273 & 939 \\
\hline 1997 & 2501 & 1729 & 772 \\
\hline 1998 & 2582 & 1972 & 610 \\
\hline 1999 & 3041 & 2547 & 494 \\
\hline 2000 & 3146 & 3363 & -217 \\
\hline 2001 & 3344 & 3156 & 187 \\
\hline 2002 & 3067 & 3677 & -610 \\
\hline 2003 & 3085 & 3785 & -700 \\
\hline 2004 & 4116 & 5222 & -1105 \\
\hline 2005 & 5413 & 6175 & -762 \\
\hline 2006 & 6960 & 8136 & -1176 \\
\hline 2007 & 9417 & 9752 & -334 \\
\hline 2008 & 13198 & 12204 & 993 \\
\hline 2009 & 8643 & 11747 & -3103 \\
\hline 2010 & 12884 & 11727 & 1157 \\
\hline 2011 & 15695 & 13140 & 2555 \\
\hline 2012 & 14142 & 15382 & -1239 \\
\hline 2013 & 16191 & 17082 & -892 \\
\hline 2014 & 16074 & 18107 & -2032 \\
\hline
\end{tabular}

Source: www.ssb.no. 
Appendix 2

Norwegian Exports to Poland as Percent of Total Exports

\begin{tabular}{|c|c|c|}
\hline SITC/Year & 2005 & 2014 \\
\hline 0 & 27.2 & 39.9 \\
\hline 6 & 23.9 & 20.0 \\
\hline 7 & 12.9 & 13.5 \\
\hline 8 & 3.1 & 3.5 \\
\hline
\end{tabular}

Source: www.ssb.no.

Appendix 3

Norwegian Imports from Poland as Percent of Total Imports

\begin{tabular}{|c|c|c|}
\hline SITC/Year & 2005 & 2014 \\
\hline 0 & 4.1 & 4.7 \\
\hline 6 & 26.2 & 26.6 \\
\hline 7 & 30.9 & 40.8 \\
\hline 8 & 22.5 & 18.4 \\
\hline
\end{tabular}

Source: www.ssb.no. 